\title{
Safety Analysis of different industries using Fuzzy AHP
}

\author{
P. Rajmohan, P.S.S. Srinivasan \\ Assistant professor, Department of Mechanical Engineering, Knowledge Institute of Technology, Tamilnadu, \\ India \\ safetyrajmohan@gmail.com \\ Professor, Department of Mechanical Engineering, Knowledge Institute of Technology, Tamilnadu, India \\ pssmech@yahoo.com
}

\begin{abstract}
In recent days, we march towards a new occupational health and safety era in which work cultures are directed towards positive safety values. It is predicted that the safety analysis techniques now in place are quite difficult to address the potential risks which weakens the era. A novel approach of analyzing different crucial criteria in different industrial sectors is analyzed carefully in this paper. In this unique approach, fuzzy AHP(Analytic Hierarchy Process) technique is applied to determine the respective weights of three main criteria and seventeen sub-criteria as a way of enriching the decision making process while in a dilemma. A survey was initiated in different industrial sectors to obtain reliable data for the research. The results shows that the main criteria 'human safety' acquired a weight of $72.5 \%$ while the respective weights of main criteria machine safety and work environment safety falls to $8.9 \%$ and $18.4 \%$. The weight of the main criteria, human safety indicates that the sub-criteria such as eye protection, manual lifting, material handling practices, fire fighting drills, training and safety officers are implemented to a greater extent in most of the surveyed industries.
\end{abstract}

\section{Indexing terms/Keywords}

Safety analysis, Fuzzy AHP, Human safety, Machine safety, Work environment safety, questionnaire survey, different industries..

\section{Academic Discipline And Sub-Disciplines}

Occupational Health and Safety

\section{SUBJECT CLASSIFICATION}

Safety Performance of different Industries

\section{TYPE (METHOD/APPROACH)}

Questionnaire Survey and application of Fuzzy AHP

\section{INTRODUCTION}

Are we safe at the working places? Many a time's industrial activities are performed in challenging and critical environments. Workers who are exposed to potential hazards at their working places are at the risks of occupational injuries and illness1,2). Over the centuries we have been a long way from industrial revolution. Undoubtedly, these growths of industries in and around India confirm that we are heading towards our economic excellence. But the occurrence of occupational accidents appears to be an alarming issue in the industries today.

As per the statistical year book, India 2016, in the year 2012-13, there are 222,120 factories in India with a total of $10,051,626$ workers3). In the year 2013, 955 factory/machine accidents are reported4). As per the report of ILO (International Labor Organization), the occupational health and safety have been improved in industries over the past 20 to 30 years. But these statistics are comparatively imprecise in developing countries because of the gaps in accident identification, reporting and records. These accidents pave way for moral, legal and financial disputes in an industry. Hence the need for improvement in industrial safety is realized at this point.

Britain Standards Institute defined risk as a combination of occurrence and results of a hazardous event).

In order to demonstrate the need for this paper, some of the post major occupational accidents in India are described which includes, Bhopal Gas Tragedy took place at Bhopal in 1984 due to the leak of the toxic Methyl Iso Cyanate (MIC) resulting in 558,125 injuries including 38,478 temporary partial injuries and approximately 3,900 severely and permanently disabling injuries. A huge fire broke out at leather factory at Kolkata on November 22, 2006 which resulted in 10 fatalities and 18 injuries. A Boiler Explosion took place at a tyre-melting unit in Coimbatore on February 12 , 2016. As a result of it, six workers suffered severe burns all over the body. High severity level of occupational accidents is observed in workplaces where more than 50 employees are engaged6). The lessons learned from these kinds of accidents are not considered for improving safety performance. This is also one of the reasons for the recurrence of occupational accidents7).

The following studies on occupational accidents should be mentioned: Efthimia K. Mihailidou.et.al. 2012 in his article recorded 319 major industrial accidents all over the world8). Valeria Casson Moreno.et.al. 2016 developed a database containing information about 167 accidents in bio-gas plants. The authors concluded that there is a need for up gradation and implementation of safety standards, safety culture and to promote awareness on risk reduction9). Romina D. Calvo Olivaresa.et.al. 2015 developed a database about accidents in the year $1998-2014$ in fuel ethanol industries. The authors declared that the machine failure is the common cause for fire accidents in the ethanol industries 10). Raphael 
Moura.et.al. 2016 developed a dataset called Multi Attribute Technological Accidents Dataset (MATAD) for grouping 238 industrial accidents11). Benjamin K. Sovacoola.et.al. 2016, carried out a study on accidents in low-carbon energy systems. The authors reported that these accidents resulted in 182,794 deaths and $\$ 265.1$ billion property damages12). The above discussions of gathered literatures rely on grouping of industrial accidents in different environments.

A lot of researches have been carried out in many industrial sectors for analyzing occupational accidents. Few researches on analysis of industrial accidents include: Yuvin Chinniah 2015 in his analysis of 106 accident reports associated with moving parts of machinery declared that machines consists of hazards in various forms that results in injuries and fatal13). Francisco Salguero Caparrosa.et.al. 2015 analysed 567 accidents occurred in the year 2009 to 2012 in various industries such as construction, manufacturing, agriculture and services and reported that these accidents occur due to deficiency in fixing minor faults and non-compliance with standards14). Vytenis Babrauskas 2016 reviewed explosion accidents in handling ammonium nitrate fertilizers7). Kwan Hyung 2016 identified the high risk groups leading to accidents in his study of industrial accidents in South Korea6). In the above literatures, the work done by various researchers should be appreciated but on the other side these findings appears to be vague and uncertain.

Yuvin Chinniah 2015 reported that even though there are lot of risk analysis techniques in practice, the occupational accidents are continuing. The author added that these accidents occur due to various factors particularly lack of risk assessment13). Moreover, the results of the above analysis appear to be insufficient in addressing the risks completely. A. Sengupta.et.al. 2015 reported that the risks in hazardous industries are expected to increase in the upcoming years. There is no appropriate system and guidelines for analyzing these risks. A different technique called the risk assessment is required to bridge the gaps in the analysis techniques15).

A formal risk assessment is necessary to identify and control all kinds of risks at workplace16). The objective of the risk assessment is to maintain risks at a permissible level at the workplaces and these techniques include work permits and Safe Job Analysis (SJA)17). Risk assessment is the qualitative examination of risk based on vulnerability of the surrounding environment. In general, there are 70 risk assessment methods in practice5). Some of the techniques include: risk estimation, safety audit, checklist analysis, what-if analysis, safety review, Preliminary Hazard Analysis (PHA), human error analysis, Hazard Operability study (HAZOP), Job Safety Analysis (JSA), Failure Mode and Effects Analysis (FMEA), Fault tree Analysis (FTA), Event Tree Analysis (ETA) etc. There are different risk analysis techniques in practice as stated above for different environments18).

Some studies that used risk assessment techniques includes: Faisal Khan.et.al. 2015 made a study on the past, present and future methods and models in process safety and risk management. These methods and models in risk management are categorized as qualitative, semi-quantitative, quantitative and hybrid19). R.E. Masto.et.al. 2015 reviewed the risks in exposure to soil and dust in coal rich zones. The author concluded that ingestion is the key route through which the soil and dust enters human body20). Peter Burgherr.et.al. 2012 developed a comparative risk assessment technique for ranking the risks in coal, oil and gas accident chains21). Jose B. Carbajo.et.al. 2015 assessed the risks in industrial waste water from personal care products industries. The assessment yielded the result that the degree of biological complexity decides the toxicity (risk) in waste water22). Hong Wang.et.al. 2012 applied risk assessment for assessing risks in industrial chemicals in China23). E. Topuz.et.al. 2011 employed integrated risk assessment for environmental and health risks in industries for prioritizing the risks sources with respect to risk classes24). Seung J. Rhee.et.al. 2003 used a new technique called Life Cost Base FMEA for measuring risk in terms of cost to arrive at the low risk design. Further, the authors applied Monte Carlo simulation to this technique to locate the uncertainties in the risk25). Wen-hui Ju 2016 recognized risks that lead to 100 fire accidents, their relevant provisions and the corresponding issues in cotton logistics using event tree and fault tree technique26). Wu Dongyin.et.al. 2015 used Event Tree Analysis (ETA) for discovering lightning risks leading to fire accidents in large scale oil tanks. In their paper, the authors proposed a model for calculating the likelihood of lightning27). Jordi Dunjóa.et.al. 2010 made a literature review on HAZOP applied to various safety issues28). Joseph Isimite.et.al. 2016 in his study of Texas City refinery explosion, sketched a model presenting the sequence of events that lead to the accident. Further the author applied HAZOP to find the risks involved in the accident29). Risto Poykio.et.al. 2016 carried out an environmental risk assessment on Bubbling Fluidized Bed (BFB) boiler area to locate the high risk metals in the ash from the boiler30).

Recent occupational accidents seem to impose a major challenge on current risk assessment techniques in reducing the probability and consequence of these accidents11).

A.Sengupta.et.al. 2015 reviewed the standards and policies related to risk assessment framework in India. The author reported that there is no appropriate system and guidelines for thoroughly analyzing the industrial risks. Further the author added that there are technical and legislative gaps in implementing the risk assessment framework15). Deficiency in risk assessment techniques may result in accidents leading to loss of lives, properties, finance and productivity. The main disadvantages of risk assessment techniques are that they are unable to address the uncertainty of the data. The concept of risk is vague and uncertain31). Kjellrun Hiis Hauge et.al. 2014 inspected and distinguished the uncertainties related to industrial risks32). The interpretation is that the risk assessment techniques failed in recognition of accurate risks leading to accidents. In addition to it, it is foreseeable that there is a gap in the present safety analysis (accident analysis and risk analysis) techniques. It can be found that there is still a demand for improved techniques for enhancing the certainty in the outcomes of the analysis. M Illankumaran.et.al. 2015 identified that there is a necessity for analysis of vast data through evaluation of crucial criteria and sub-criteria33).

Studies proposed risks in a different approach: Mahmood Shafiee.et.al. 2015 stated that risk is a multi-criteria decision (MCDA) problem and it is obligatory to rank the possible alternatives for controlling these risks34). Christer Carlsson.et.al. 1996 studied the recent developments in fuzzy MCDM and proposed some group of methods such as (i) the outranking, (ii) the value and utility theory based, (iii) the multiple objective programming, and (iv) group decision and negotiation theory based methods35). Yi Peng.et.al. 2011 studied agro meteorological disaster that occurred in China in 1997 and 2001 using MCDM for identifying and mitigating the risks in proper time36).

5968 | P a g e 
Fuzzy logic includes numerous techniques such as TOPSIS (Technique for Order of Preference by Similarity to Ideal Solution), COPRAS, AHP, SAW etc. M. Ilangkumaran.et.al. 2015 applied Hybrid MCDM technique Analytic Network Process (ANP) and Fuzzy Linguistic approach) for risk analysis to evaluate the safety performance of hot environment in foundry industry33). Among these techniques Fuzzy AHP is one of the simple method and easy to use. Thomas Saaty first applied the fuzzy AHP method for solving problems containing multi decision criterion34)

Application of fuzzy AHP in different fields: AHP is used for addressing multi criterion vague problems that may be either qualitative or quantitative. Metin Dağdeviren.et.al. 2008 proposed fuzzy AHP for a real manufacturing company for determining the Faulty Behaviour Risk (FBR) in work system. He weighted faulty behaviour with triangular fuzzy numbers through pair wise comparisons and evaluated the factors using fuzzy linguistic variables. He concluded that this is the paramount way through which faulty behaviour is prevented and safety of work system is improved37). Guozhong Zheng.et.al. 2012 applied trapezoidal Fuzzy AHP for hot and humid environments with the criteria work, environment and workers for identifying the workers performance38). Zeyang Song.et.al. 2014 employed trapezoidal and the triangular extent fuzzy AHP methods for identifying the early warning system for self-ignition risks in coal piles. In a comparison of trapezoidal fuzzy AHP with triangular extent fuzzy AHP, the authors concluded that the triangular fuzzy AHP is more reliable for evaluation of self-ignition risks of coal39). Debasish Majumder.et.al. 2013 used fuzzy AHP for analyzing the risks in construction sites40). SHI Shiliang.et.al.2011 used fuzzy AHP for evaluating the risk of falling from height to prioritize the control techniques for controlling these risks41). Mohsen Askari.et.al. 2014 proposed a fuzzy AHP Hierarchy system for construction industries with criteria such as time, cost, quality and scope42). Shapira (2005) established fuzzyAHP in building sites to rank the 21 various organizational, technical, environmental and human factors on work safety43). J.H.M. Tah V. Carr 2000 used fuzzy AHP logic for risk assessment in construction projects44). Osman Taylan.et.al. 2014 used fuzzy AHP and fuzzy TOPSIS for selecting and assessing the risks in construction projects16). Sahar Rezaian.et.al. 2012 used multi criteria decision method called fuzzy AHP for risk assessment in refineries to rank the crucial factors5). Evelyn Enchill.et.al. 2015 developed Fuzzy AHP hierarchy for gas manufacturing company (Ghana) for ranking the criteria such as human, organizational, technical and environmental factors with the sub criteria Acetylene Plant, Carbon dioxide Plant, oxy nitrogen plant, obtained through the data collected from the experts and workers in safety and production field45).

It can be realized from the above discussions that fuzzy AHP has wider scope of influence in safety analysis. Hence it can be recommended as an alternative for existing safety analysis techniques. However it is important to note that fuzzy AHP cannot be used as a substitute for risk analysis techniques. It is true from the above discussions that AHP could be applied for analysis of safety in industries. Hardly few researches focus on application of fuzzy AHP in safety analysis. Unfortunately, of those few, no gathered literatures have hands on analysis of safety through evaluation of crucial criteria in different industries. Hence in this paper, three main criteria and seventeen sub-criteria are proposed for analysis of different industries through fuzzy AHP. Fuzzy AHP is used for estimating and ranking the respective weights of proposed criteria. The reliable data for the work is obtained through a questionnaire survey. The final judgments are arrived based on the rank of the individual criteria. Most exclusively, this paper explains the present status of defined criteria in various industries through the leverage of data from survey and knowledge of industrial experts.

\section{MOTIVATION FOR RESEARCH}

Owing to large manpower, resources and good economic conditions India seems to be a best place for investing and starting industries. Due to these reasons, business people from all over the world are attracted towards India. And also, the industrial revolution has contributed to large number of industries all over India. However these industries play a vital role in contribution to India's economy, it has been observed that there are large number of occupational accidents in these industries. Some of them are listed:

Bhopal Gas Tragedy which took place at Bhopal on 1984 due to the leak of the toxic Methyl Iso Cyanate (MIC) resulting in 1984558,125 injuries, including 38,478 temporary partial injuries and approximately 3,900 severely and permanently disabling injuries. A huge fire broke out at leather factory at Kolkata on November 22, 2006 which resulted in 10 fatalities and 18 injuries. The fire broke when the hydrocarbon and wielding gas came into contact and soon after triggered an explosion at IPCL plant on 06 June, 2008. Four people were killed and 46 others were injured. A chimney collapse occurred on 23 September, 2009 in a construction under contract for the Bharat Aluminium Co Ltd (BALCO) killing 45 people. Two explosions broke out at Ankleshwar-based chemical dye manufacturing unit on Tuesday 06 January, 2009 which killed three workers and severely injured two other. The entire unit has been damaged in the explosion. A fire broke out at Indian Oil Corporation on 29 October 2009 in an oil depot tank. The depot fire raged for 11 days, 12 people were killed and over 200 were injured resulted in losses worth INR 2.80 billion and during the period half a million people were evacuated from the area. A huge fire broke out at a pharmaceutical company in Andhra on December 19, 2011 and spread to neighboring factories. More than six workers had been injured in the fire. A fire accident broke out at a private thermal power plant in Tuticorin on 15 August 2011. Four employees were killed and six were severely injured. On 5 September 2012 an explosion broke out at a fireworks factory in Sivakasi. 40 people were killed and more than 70 were injured. People killed included factory workers and local villagers who walked in after the initial fire. An industrial incident at Ambuja Cement's plant due to a fly-ash hopper situated on the fifth floor was allegedly overloaded during a maintenance operation and collapsed and crashed four floors below. There was a huge blast in the reactor at a pharma unit on September 28, 2015 and the factory was engulfed in smoke. Two workers were killed and five wounded. Of the five wounded, the condition of one worker was said to be critical. A demand of compensation of INR 30 lakh a piece was given to the families of the dead workers. A Boiler Explosion took place in a tyre-melting unit at Coimbatore on February 12 , 2016. As a result of it, six workers suffered severe burns all over the body.

5969 | P a g e 
One of the most important phases in health and safety is the assessment of risks in an industry. It can be observed from the above case studies from the period 1984-2016, though lot of safety management systems and risk assessment techniques are in practice, the occurrence of occupational accidents goes on continuing. It can be realized that these systems are insufficient in addressing the risks entirely.

\section{FUZZY AHP}

Which one to select? Or which one is best among a set of alternatives? Solutions for these questions are obtained through fuzzy AHP. Despite going in-depth, literal points related to fuzzy AHP mechanisms are briefed. Fuzzy AHP is one of the most widely used technique in numerous research papers as it provides solid advice for solving Multi Criteria Decision Problems (MCDM - linguistic variables that are vague and uncertain)46). Prof. Thomas L. Saaty first introduced AHP (1970) for solving MCDM problems and it seems to be effortless. Saaty defined AHP as a method of "measurement through pair wise comparisons and relies on the judgments of experts to derive priority scales" $47,48,49$, 50).

Through the application of simple maths, AHP yields both quantitative and qualitative results. AHP involves dividing problems into hierarchy of criteria followed by calculation of their respective weights. Then based on the weights obtained, the criteria are compared and ranked through pair-wise comparison. Finally, decisions are obtained based on the rank of the criteria.

AHP Algorithm

(Rosaria de F. S. M. Russo, Roberto Camanho, 2015) the sequence of steps involved in AHP is stated as51):

Step 1: Definition of Problem:

(i) Initially the problem to be analyzed is chosen.

(ii) The corresponding criteria and sub-criteria relevant to the problem are identified through any data collection methods.

Step 2: Organizing the Decision Hierarchy:

(i) The Hierarchical structure consists of three stages: $\quad$ (i) Objective (ii) Criteria (iii) Sub-criteria.

(ii) The sub-criteria are defined in relation to the main criteria as shown in the figure 1.

Step 3: Building Comparison Matrix: Comparison is built as follows:

(i) The criteria in stage II is compared with the sub-criteria in the stage III respectively i.e. each criterion is compared with all the sub-criteria irrespective of the criteria it is defined with.

(ii) A matrix is developed for the each and every criterion in stage II.

(iii) A rating scale is defined with qualitative and quantitative data as shown in table 1.

(iv) In case of criteria in the column is preferred to the criteria in the row, then the inverse of the rating is defined i.e. if row is preferred than to column, row is rated at the exact

rating as defined in the scale or else if column is preferred than to rows, the inverse of the rating value is considered. The lower triangular matrix is filled by using the reciprocal of the upper diagonal. Let aij is the element if row 'i' and column ' $j$ ', if so, the lower diagonal is defined as:

Step 4: Pairwise comparison:

$$
\sigma i=\begin{gathered}
1 \\
---
\end{gathered}
$$

(i) Then the fraction values are converted into decimal values.

(ii) Next step is to add all the values in each row.

Step 5: Normalization:

(i) Then the fraction values are converted into decimal values.

(ii) The matrix is normalized by adding up all the values in each column and the average of each column ( $\lambda$ max).

Step 6: Estimation of Consistency Analysis:

There are 3 steps for calculation of consistency ratio:

(i) Calculate the consistency measure and Consistency Index (CI).

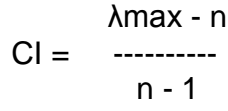

(ii) Estimating the Consistency Ratio (Cl/RI).

$$
\mathrm{CR}=\mathrm{Cl} / \mathrm{RI}
$$

Where $\mathrm{RI}=$ Random Index and is given by:

Step 7: Approximation of consistency index:

(i) Each and every column of pair wise comparison matrix is multiplied by their equivalent relative weights.

(ii) The addition results of the rows are divided by their equivalent relative weights.

(iii) The average of the values from step 2 is denoted by $\lambda \max$

$$
\mathrm{Cl}=\frac{\lambda \max -\mathrm{n}}{\mathrm{n}-1} \quad \text { (approximate) }
$$

Step 8: Estimation of Consistency Ratio (CR):

(i) Usually, a CR value of 0.1 or below is considered acceptable.

(ii) The values greater than 0.1 , points to revision of criteria. 


\section{SAFETY EVALUATION OF THE SYSTEM}

The essential evidence for the research is obtained through a questionnaire survey conducted in five different industries (Heavy engineering, automobile, manufacturing, and foundry and textile industry). In the initial step, the fine points about industries in southern part of Tamilnadu are collected and scrutinized. This study yields the result that the above mentioned industries are the major industrial sectors that covers most of the industries in the local area. This motivated the authors to consider these industries. The population involved in the survey includes personnel's such as casua labours, contractors, technicians, maintenance supervisors, shift supervisors, production managers and safety manager. Table 2 shows the particulars of participants involved in the survey.

A sample filled in questionnaire is shown in Appendix 1. The results of the survey are analyzed by using a team of five experts who have vast industrial experience in the areas of production, maintenance, engineering, quality and safety. The final pair wise comparison matrix is developed based on the decisions of the expert's team.

The proposed methodology consists of three phases: Phase I: Data collection, Phase: II: AHP Computation and Phase III: Evaluation of criteria. The algorithm of the proposed approach is shown in fig 1.

\section{EVALUATION OF CRITERIA}

Safety atmosphere differs from industries to industries. The selected industries are those which may give the most and least priority to safety in their business. In order to narrow down the areas to be focused in these industries, several criteria were defined initially based on suggestions from a team of experts. It includes three main criteria and seventeen sub-criteria. These criteria are the elements to look at in these industries which are grouped under a label called main criteria namely Human Safety, Machine Safety and Work environment Safety attributes. The grouping is done as follows: 1 . Human safety attributes takes interest in sub-criteria such as eye protection, manual lifting, material handling practices, Fire Fighting drills, Training and Safety officer, 2. Machine safety attributes includes sub-criteria such as fencing, revolving parts protection, safe work speed, pressure plant protection, power cut-off devices, 3 . Work environment safety attributes includes sub-criteria such as manhole protection, explosion safety, lightening protection, flammable dust prevention, pits, sumps protection and portable light usage. The decision model projecting main criteria and their respective sub-criteria is shown in figure 2 .

\section{CASE STUDY}

In this paper, application of the proposed model includes evaluation of a real time problem faced by industries today. Heavy engineering industry included in the survey involve in production of construction \& mining machineries including compact dump trucks, excavators, backhoe loaders, motor graders, bulldozers and skid steer loaders and industrial machineries employing more than 1600 people. Whereas automobile industry manufactures auto components such as clutch plates, chains and sprockets, fly wheel housing, gear housing, lube oil cooler cover assembly, filter head, air connectors, clutch housing, filtration module casting, turbo charger, compressor cover assembly, fuel pump housing, crank case, cylinder head etc. with a total of more than 1,100 employees. Manufacturing industry referred to in this survey own a business of hand tools, metal forgings, metal stampings etc. with 790 employees working round the clock. Foundry involves in casting of components for textile, automobile, machine tools etc. with manpower of 550 people. Textile industry involves in the business of production of yarn from cotton fibres and poly ester with strength of around 663 workers. The goal of this paper is to rank the criteria and sub-criteria based on their respective weights and to decide on the criteria that still needs improvements. The linguistic terms used for construction of pair wise comparison matrix is shown in the table 3.

\section{AHP WORK OUT}

AHP enhances the interpretation of decision making problems. The proposed AHP involves the following steps: Initially the evaluated criteria are disintegrated into a decision hierarchy as shown in Fig 1 which includes the objectives, main criteria and sub-criteria defined under them. Then the pair wise comparison matrix is formed for each main criteria and sub-criteria for determining their respective weights. Through pair wise comparison each main criterion is compared with other main criteria and in a similar way each sub-criterion is compared with the other relevant sub-criteria. Table 4 shows the pair wise comparison matrix of main criteria and sub-criteria. In the next step, the resultant values drawn from pair wise matrices are normalized. The final step is the calculation of the consistency index and consistency ratio (CR $<$ $0.1)$ to evaluate consistency of the constructed pair wise matrix. Table 5 shows the respective weights and consistency values of main and sub-criteria respectively.

Table 12 shows the respective weights of main criteria, sub-criteria and industries. The following data are extracted from the table 12 . The respective weights of the three main criteria are Human safety attributes (0.72), Machine safety attributes (0.089), and work environment safety attributes $(0.184)$.

It can be observed from the second column of table 12 that the human safety attribute tops the weights with a weight of $72.5 \%$. It indicates that the sub-criteria of human safety eye protection $(0.189)$, manual lifting $(0.442)$, material handling practices (0.053), fire fighting drills (0.086), training (0.040), and safety officer $(0.191)$ are found to be mostly followed by all industries. In addition to it, it is practical that most of the sub-criteria material handling practices, fire fighting drills, training and safety officer under the main criteria human safety falls under administrative controls and it requires an experienced or competent persons to train the workers which costs low and he may be the safety manager. The respective weights of the machine safety and work environment safety are $8.9 \%$ and $18.4 \%$. The weight of machine safety attribute seems to be very low which depicts that the sub-criteria fencing $(0.105)$, revolving parts protection $(0.171)$, safe

5971 | P a g e

March 2017

w w w. cirworld.com 
work speed (0.246), pressure-plant protection (0.402), power cut-off devices (0.073) under it needs continual improvements. It can be observed that the management's shows no or less interest in automation of machines. This may be due to involvement of huge investments in modification or replacement of machines. It shall be appreciable that if employers concentrate on engineering controls and proper work methods for reducing workplace hazards and risks. It is also concrete that sub-criteria under work environment safety manhole protection (0.064), explosion safety (0.350), lightening protection (0.172), flammable dust prevention (0.259), pits, sumps protection (0.050), and portable light usage (0.102) are being done during the erection and commissioning phases of an industry. The low weight of the work environment safety attributes $(18.4 \%)$ may be due to improper maintenance work done in preserving the conditions of the sub-criteria.

It can be observed from the fourth column of table 12 with respect to human safety attributes that the manual lifting sub-criteria leads with a weight of $44.2 \%$. This may be due to the fact that most of the materials in the surveyed industries are lifted manually. It can be observed that proper trainings are being provided to the workers during their induction period and refreshed periodically for manual lifting activities. The weights of the remaining sub-criteria eye protection, material handling practices, firefighting drills, training, and safety officers are found to be low which may be due to improper control methods for identified hazards and non-availability of competent persons for training the workers.

With respect to machine safety attribute that the sub-criteria pressure plant protection has a maximum weight of $40.2 \%$. This is because of the point that the manufacturer of pressure plants ensures essential safety devices are in-built into the pressure plants before delivering to its customers. However the responsibilities of monitoring and maintenance of the devices falls on the responsibility of management of the individual industries. As already stated the sub-criteria fencing, revolving parts protection, power cut-off devices involves phases of purchasing or fabrication, installation, execution and monitoring costs for all the machineries in a plant which involves huge costs. So, the management shows less importance in implementation of the above sub-criteria.

The sub-criteria explosion safety under work environment safety attribute has an imperative function with a weight of $35 \%$. This could be possible because it can be observed during the survey that the flammables and explosives are stored in an isolated area with essential safety precautions. The respective weights of the remaining sub-criteria under main criteria work environment safety attribute are manhole protection, lightening protection, flammable dust prevention, pits, sumps protection and portable light usage are $6.4 \%, 17.2 \%, 25.9 \%, 5 \%$ and $10 \%$ respectively. The low weights of sub-criteria manhole protection, lightening protection, pits, sumps protection may be due to inadequate maintenance resources and persons for preserving their conditions.

The following discussions are made in liaison with positions of individual industries based on sub-criteria as shown in fig 1. When viewed heavy engineering industry as a separate chapter, it is liable that these industries shows an upper hand while comparing with other industries. This could be possible due to the fact that most of the heavy engineering industries are multinational corporations where they have distinct management systems and guidelines for managing industrial safety. It can be fathomable that the implementation and monitoring of these systems has a positive impact on safety which could be realized through the comparison with different industries. In this survey, it is also likely that the textile industry stands last in most of the sub-criteria. From the analysis and feedbacks from relevant industry experts and workers it can be grasped that the production is seen as a more vital factor than safety in these industries. In addition to the above theme, most of the textile industries falls under small scale segment and hence the attitude is narrowed to profit making i.e. return on investment. Hence there is a need for immediate drift for improving the sub-criteria to cope up with other industries performance. The ultimate implication could be that the heavy engineering and the textile industries has their trails on two opposite extremes in implementation of safety.

Whereas from the analysis it is clear that the foundry positions themselves a step ahead of textile industries. But as similar to textile industries, foundry has to travel a long way for achieving safety excellence. It can be witnessed that the manufacturing has a lower hand in comparison with heavy engineering but shows an upper hand in comparison with automobile. It signifies that the manufacturing industry should concentrate on all the sub-criteria except fencing for continual improvement in safety. In a similar comparison, automobile industry lags behind manufacturing but ranks ahead of foundry. Hence the automobile industry should caution on all the sub-criteria except safe work speed for improving the performance of safety.

\section{CONCLUSION:}

Through this novel approach, safety performance of different industries is analyzed using fuzzy AHP to determine the uncertainty in decision making process. The respective weights of main criteria and sub-criteria were calculated based on the data obtained through the survey. These weights are then analyzed to arrive at the rankings of individual criteria and sub-criteria. An innovative approach for analysis of safety criteria in industries is visualized though this paper. This approach will be in place as a guide for the researchers and industry professionals for exact analysis and ranking of safety parameters based on individual priorities.

Table 1. Values of Random Index

\begin{tabular}{|c|c|c|c|c|c|c|c|c|c|c|}
\hline $\mathrm{N}$ & 1 & 2 & 3 & 4 & 5 & 6 & 7 & 8 & 9 & 10 \\
\hline $\mathrm{RI}$ & 0.00 & 0.00 & 0.58 & 0.9 & 1.12 & 1.24 & 1.32 & 1.41 & 1.46 & 1.49 \\
\hline
\end{tabular}

5972 | P a g e 
Where $\mathrm{N}=$ order of matrix

Table 2. Particulars of participants involved in the survey

\begin{tabular}{|c|c|}
\hline Description & Details \\
\hline Age & $25-45$ years \\
\hline Gender & Male and Female \\
\hline Education & Illiterate to Doctorates \\
\hline Experience & $0-20$ years \\
\hline Organization level & $\begin{array}{c}\text { Low level employees to Senior } \\
\text { level managers }\end{array}$ \\
\hline
\end{tabular}

Table 3. Linguistic terms for pair wise comparison

\begin{tabular}{|c|c|}
\hline Linguistic terms & Numbers \\
\hline Equally Important & $(1,1,1)$ \\
\hline Slightly important than other & $(1,3,5)$ \\
\hline Strong Important & $(3,5,7)$ \\
\hline Very Strong Important & $(5,7,9)$ \\
\hline Absolute Important & $(9,9,10)$ \\
\hline
\end{tabular}

Table 4. Pair wise comparison of main criteria

\begin{tabular}{|c|c|c|c|c|c|c|c|c|c|}
\hline Goal & \multicolumn{3}{|c|}{ HS } & \multicolumn{3}{c|}{ MS } & \multicolumn{3}{c|}{ WES } \\
\hline HS & 1.0 & 1.0 & 1.0 & 5.0 & 7.0 & 9.0 & 3.0 & 5.0 & 7.0 \\
\hline MS & 0.1 & 0.1 & 0.2 & 1.0 & 1.0 & 1.0 & 0.2 & 0.3 & 1.0 \\
\hline WES & 0.1 & 0.2 & 0.3 & 1.0 & 3.0 & 5.0 & 1.0 & 1.0 & 1.0 \\
\hline
\end{tabular}

Table 5. Respective weights and consistency values of main criteria

\begin{tabular}{|c|c|c|c|}
\hline Criteria & Weights & Cl & CR \\
\cline { 1 - 2 } HS & 0.725628 & & \\
\cline { 1 - 2 } MS & 0.08955 & 0.032444 & 0.055938 \\
\cline { 1 - 2 } WES & 0.184823 & & \\
\hline
\end{tabular}

Table 6. Pair wise comparison of sub-criteria under human safety

\begin{tabular}{|c|c|c|c|c|c|c|c|c|c|c|c|c|c|c|c|c|c|c|}
\hline $\begin{array}{l}\text { Human } \\
\text { Safety }\end{array}$ & \multicolumn{3}{|c|}{ EP } & \multicolumn{3}{|c|}{ ML } & \multicolumn{3}{|c|}{ MHP } & \multicolumn{3}{|c|}{ FFD } & \multicolumn{3}{|c|}{ TG } & \multicolumn{3}{|c|}{ SO } \\
\hline EP & 1.0 & 1.0 & 1.0 & 0.2 & 0.3 & 1.0 & 1.0 & 3.0 & 5.0 & 1.0 & 3.0 & 5.0 & 1.0 & 3.0 & 5.0 & 1.0 & 3.0 & 5.0 \\
\hline ML & 1.0 & 3.0 & 5.0 & 1.0 & 1.0 & 1.0 & 5.0 & 7.0 & 9.0 & 5.0 & 7.0 & 9.0 & 9.0 & 9.0 & 10.0 & 1.0 & 3.0 & 5.0 \\
\hline MHP & 0.2 & 0.3 & 1.0 & 0.1 & 0.1 & 0.2 & 1.0 & 1.0 & 1.0 & 0.1 & 0.2 & 0.3 & 1.0 & 3.0 & 5.0 & 0.1 & 0.2 & 0.3 \\
\hline FFD & 0.2 & 0.3 & 1.0 & 0.1 & 0.1 & 0.2 & 3.0 & 5.0 & 7.0 & 1.0 & 1.0 & 1.0 & 1.0 & 3.0 & 5.0 & 0.1 & 0.2 & 0.3 \\
\hline
\end{tabular}




\begin{tabular}{|c|c|c|c|c|c|c|c|c|c|c|c|c|c|c|c|c|c|c|} 
TG & 0.2 & 0.3 & 1.0 & 0.1 & 0.1 & 0.1 & 0.2 & 0.3 & 1.0 & 0.2 & 0.3 & 1.0 & 1.0 & 1.0 & 1.0 & 0.1 & 0.2 & 0.3 \\
\hline SO & 0.2 & 0.3 & 1.0 & 0.2 & 0.3 & 1.0 & 3.0 & 5.0 & 7.0 & 3.0 & 5.0 & 7.0 & 3.0 & 5.0 & 7.0 & 1.0 & 1.0 & 1.0 \\
\hline
\end{tabular}

Table 7. Respective weights and consistency values of sub-criteria under human safety

\begin{tabular}{|c|c|c|c|}
\hline Criteria & Weights & & \\
\hline EP & 0.189086 & $\mathrm{Cl}$ & CR \\
\hline ML & 0.442112 & \multirow{5}{*}{0.121003075} & \multirow{5}{*}{0.0975} \\
\hline MHP & 0.051269 & & \\
\hline FFD & 0.086097 & & \\
\hline TG & 0.040407 & & \\
\hline SO & 0.191029 & & \\
\hline
\end{tabular}

Table 8. Pair wise comparison of sub-criteria under machine safety

\begin{tabular}{|c|c|c|c|c|c|c|c|c|c|c|c|c|c|c|c|}
\hline $\begin{array}{c}\text { Machine } \\
\text { Safety }\end{array}$ & \multicolumn{3}{|c|}{ FG } & \multicolumn{3}{c|}{ RPP } & \multicolumn{3}{c|}{ SWS } & \multicolumn{3}{c|}{ PPP } \\
\hline FG & 1.0 & 1.0 & 1.0 & 0.2 & 0.3 & 1.0 & 0.2 & 0.3 & 1.0 & 0.1 & 0.2 & 0.3 & 1.0 & 3.0 & 5.0 \\
\hline RPP & 1.0 & 3.0 & 5.0 & 1.0 & 1.0 & 1.0 & 0.2 & 0.3 & 1.0 & 0.2 & 0.3 & 1.0 & 1.0 & 3.0 & 5.0 \\
\hline SWS & 1.0 & 3.0 & 5.0 & 1.0 & 3.0 & 5.0 & 1.0 & 1.0 & 1.0 & 0.2 & 0.3 & 1.0 & 1.0 & 3.0 & 5.0 \\
\hline PPP & 1.0 & 3.0 & 5.0 & 1.0 & 3.0 & 5.0 & 1.0 & 3.0 & 5.0 & 1.0 & 1.0 & 1.0 & 3.0 & 5.0 & 7.0 \\
\hline PCD & 0.2 & 0.3 & 1.0 & 0.2 & 0.3 & 1.0 & 0.2 & 0.3 & 1.0 & 0.1 & 0.2 & 0.3 & 1.0 & 1.0 & 1.0 \\
\hline
\end{tabular}

Table 9. Respective weights and consistency values of sub-criteria under machine safety

\begin{tabular}{|c|c|c|c|}
\hline Criteria & Weights & Cl & CR \\
\hline FG & 0.105343 & \multicolumn{1}{|c|}{} & \\
\cline { 1 - 2 } RPP & 0.171789 & & \\
\cline { 1 - 2 } SWS & 0.246311 & 0.06861 & 0.06125 \\
\cline { 1 - 2 } PPP & 0.402731 & & \\
\hline PCD & 0.073826 & & \\
\hline
\end{tabular}

Table 10. Pair wise comparison of sub-criteria under work environment safety

\begin{tabular}{|c|c|c|c|c|c|c|c|c|c|c|c|c|c|c|c|c|c|c|}
\hline $\begin{array}{c}\text { Work } \\
\text { Environment }\end{array}$ & \multicolumn{3}{|c|}{ MP } & \multicolumn{3}{|c|}{ ES } & \multicolumn{3}{|c|}{ LP } & \multicolumn{3}{|c|}{ FDP } & \multicolumn{3}{|c|}{ PSP } & \multicolumn{3}{|c|}{ PLU } \\
\hline MP & 1.0 & 1.0 & 1.0 & 0.1 & 0.1 & 0.2 & 0.2 & 0.3 & 1.0 & 0.1 & 0.2 & 0.3 & 1.0 & 3.0 & 5.0 & 0.2 & 0.3 & 1.0 \\
\hline ES & 3.0 & 5.0 & 7.0 & 1.0 & 1.0 & 1.0 & 1.0 & 3.0 & 5.0 & 1.0 & 3.0 & 5.0 & 3.0 & 5.0 & 7.0 & 1.0 & 3.0 & 5.0 \\
\hline LP & 1.0 & 3.0 & 5.0 & 0.2 & 0.3 & 1.0 & 1.0 & 1.0 & 1.0 & 0.2 & 0.3 & 1.0 & 1.0 & 3.0 & 5.0 & 3.0 & 5.0 & 7.0 \\
\hline FDP & 3.0 & 5.0 & 7.0 & 0.2 & 0.3 & 1.0 & 1.0 & 3.0 & 5.0 & 1.0 & 1.0 & 1.0 & 3.0 & 5.0 & 7.0 & 1.0 & 3.0 & 5.0 \\
\hline PSP & 0.2 & 0.3 & 1.0 & 0.1 & 0.2 & 0.3 & 0.2 & 0.3 & 1.0 & 0.1 & 0.2 & 0.3 & 1.0 & 1.0 & 1.0 & 0.2 & 0.3 & 1.0 \\
\hline PLU & 1.0 & 3.0 & 5.0 & 0.2 & 0.3 & 1.0 & 0.1 & 0.2 & 0.3 & 0.2 & 0.3 & 1.0 & 1.0 & 3.0 & 5.0 & 1.0 & 1.0 & 1.0 \\
\hline
\end{tabular}

Table 11. Respective weights and consistency values of sub-criteria under work environment safety

\begin{tabular}{|l|l|l|l|}
\hline Criteria & Weights & $\mathrm{Cl}$ & $\mathrm{CR}$ \\
\hline
\end{tabular}




\begin{tabular}{|c|c|c|c|}
\hline MP & 0.06432 & & \\
\cline { 1 - 2 } ES & 0.35058 & & \\
\cline { 1 - 2 } LP & 0.17234 & \multirow{3}{*}{0.1201} & \multirow{2}{*}{0.09685} \\
\cline { 1 - 2 } FDP & 0.25916 & & \\
\hline PSP & 0.05081 & & \\
\cline { 1 - 2 } PLU & 0.1028 & & \\
\hline
\end{tabular}

Table 12. Respective weights of main criteria, sub-criteria and industries

\begin{tabular}{|c|c|c|c|c|c|c|c|c|}
\hline \multirow{2}{*}{$\begin{array}{l}\text { Main } \\
\text { Criteria }\end{array}$} & \multirow{2}{*}{ Weight } & \multirow{2}{*}{ Sub Criteria } & \multirow{2}{*}{ Weight } & \multicolumn{5}{|c|}{ Industries } \\
\hline & & & & $\begin{array}{c}\text { Heavy } \\
\text { Engineering }\end{array}$ & Automobile & Manufacturing & Foundry & $\begin{array}{l}\text { Textile } \\
\text { Industry }\end{array}$ \\
\hline \multirow{6}{*}{$\begin{array}{l}\text { Human } \\
\text { safety } \\
\text { Attributes }\end{array}$} & \multirow{6}{*}{0.725628} & Eye Protection & 0.1891 & 0.49 & 0.26 & 0.14 & 0.05 & 0.06 \\
\hline & & Manual Lifting & 0.4421 & 0.42 & 0.1793 & 0.2569 & 0.0846 & 0.0592 \\
\hline & & $\begin{array}{l}\text { Material } \\
\text { Handling } \\
\text { Practices }\end{array}$ & 0.053 & 0.0517 & 0.1303 & 0.091 & 0.2423 & 0.4848 \\
\hline & & $\begin{array}{c}\text { Fire Fighting } \\
\text { Drills }\end{array}$ & 0.0861 & 0.5772 & 0.2077 & 0.1138 & 0.0596 & 0.0417 \\
\hline & & Training & 0.0404 & 0.5315 & 0.126 & 0.2047 & 0.088 & 0.0498 \\
\hline & & Safety Officer & 0.191 & 0.4545 & 0.2434 & 0.1929 & 0.0707 & 0.0306 \\
\hline \multirow{5}{*}{$\begin{array}{l}\text { Machine } \\
\text { Safety } \\
\text { Attributes }\end{array}$} & \multirow{5}{*}{0.08955} & Fencing & 0.1053 & 0.2695 & 0.1156 & 0.3873 & 0.1653 & 0.0623 \\
\hline & & $\begin{array}{l}\text { Revolving Parts } \\
\text { Protection }\end{array}$ & 0.1718 & 0.444 & 0.27 & 0.1885 & 0.0676 & 0.0298 \\
\hline & & $\begin{array}{l}\text { Safe Work } \\
\text { Speed }\end{array}$ & 0.2463 & 0.2843 & 0.4084 & 0.1745 & 0.0823 & 0.0506 \\
\hline & & $\begin{array}{l}\text { Pressure Plant } \\
\text { Protection }\end{array}$ & 0.4027 & 0.4365 & 0.1631 & 0.2853 & 0.0767 & 0.0384 \\
\hline & & $\begin{array}{l}\text { Power cut-off } \\
\text { Devices }\end{array}$ & 0.0738 & 0.418 & 0.1784 & 0.2557 & 0.096 & 0.0519 \\
\hline \multirow{4}{*}{$\begin{array}{c}\text { Work } \\
\text { Environment } \\
\text { Safety } \\
\text { Attributes }\end{array}$} & \multirow{4}{*}{0.184823} & $\begin{array}{l}\text { Manhole } \\
\text { Protection }\end{array}$ & 0.0643 & 0.4149 & 0.1771 & 0.2539 & 0.1086 & 0.0455 \\
\hline & & $\begin{array}{l}\text { Explosion } \\
\text { Safety }\end{array}$ & 0.3506 & 0.4408 & 0.1534 & 0.2507 & 0.1079 & 0.0473 \\
\hline & & $\begin{array}{l}\text { Lightening } \\
\text { Protection }\end{array}$ & 0.1723 & 0.3873 & 0.1653 & 0.2695 & 0.1156 & 0.0623 \\
\hline & & $\begin{array}{c}\text { Flammable } \\
\text { Dust Prevention }\end{array}$ & 0.2592 & 0.418 & 0.096 & 0.2557 & 0.1784 & 0.0519 \\
\hline
\end{tabular}




\begin{tabular}{|l|c|c|c|c|c|c|c|c|}
\hline & & $\begin{array}{c}\text { Pits, Sumps } \\
\text { Protection }\end{array}$ & 0.0508 & 0.4592 & 0.1509 & 0.2471 & 0.0928 & 0.0499 \\
\cline { 2 - 7 } & $\begin{array}{c}\text { Portable Light } \\
\text { Usage }\end{array}$ & 0.1028 & 0.4609 & 0.141 & 0.282 & 0.0759 & 0.0402 \\
\hline
\end{tabular}

Fig 1. Proposed Methodology for ranking and evaluation of criteria's in individual industries 


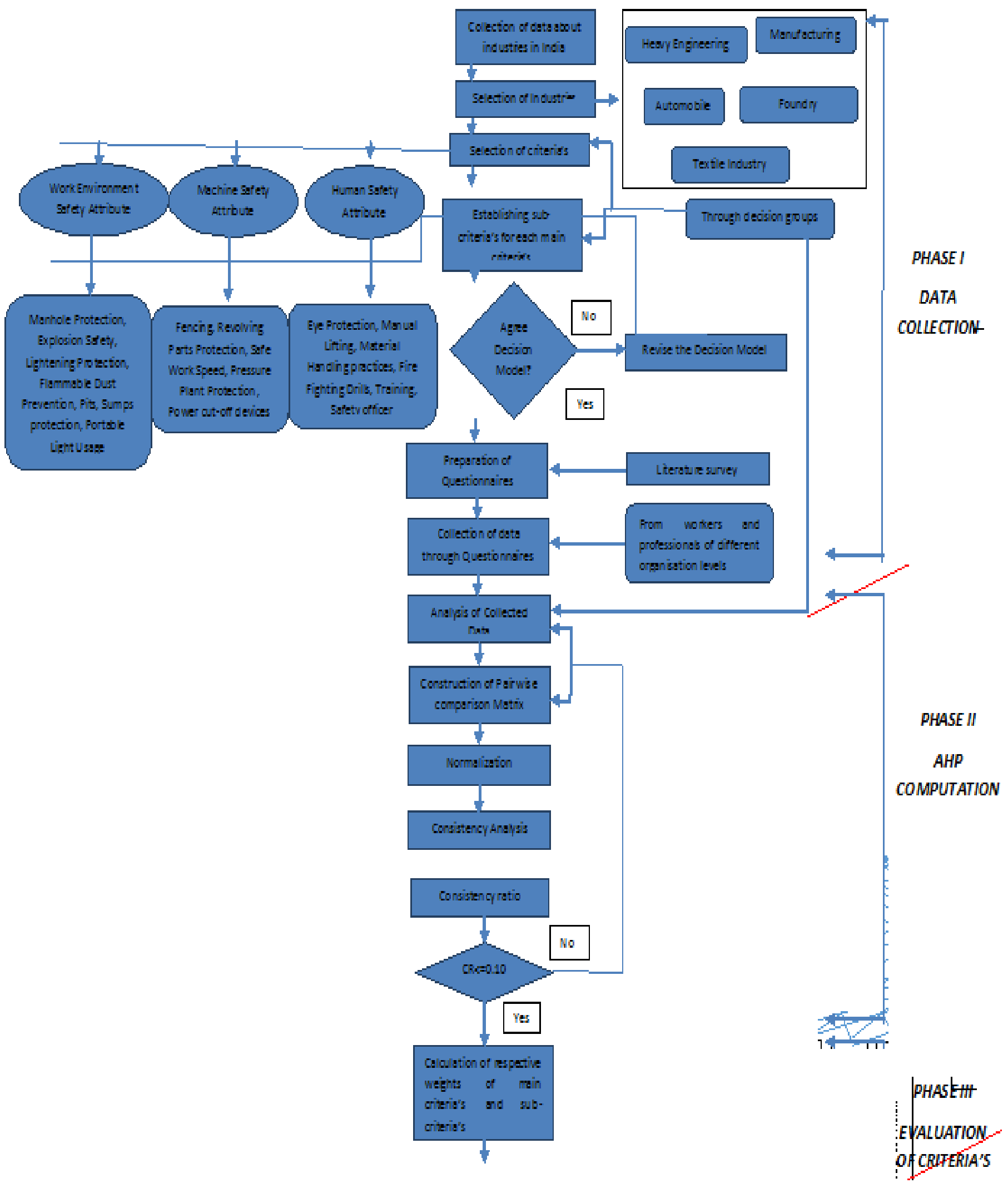




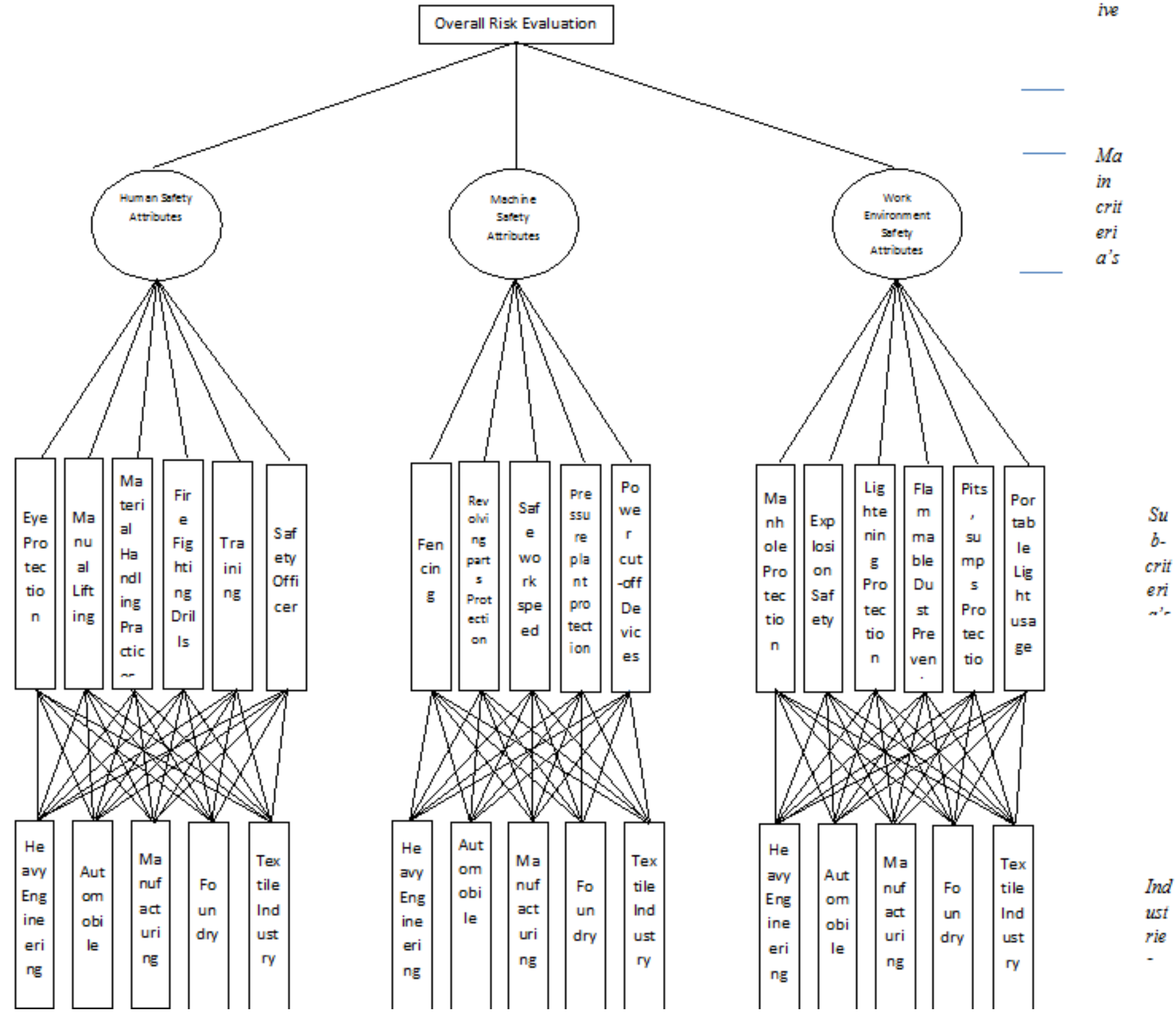

\section{ACKNOWLEDGMENTS}

This project was supported by the "EHS department" in various Indian industries. The authors extend particular thanks to the administration and EHS staffs in the company participated in the study. We thank for their support during the research study.

\section{REFERENCES}

1. Akalp, G. Aytac, S. Yamankaradeniz, N. Cankaya, O. Gokce, A. Tufekci U. 2015. Perceived safety culture and occupational risk factors among women in metal industries: A study in Turkey. International Conference on Applied Human Factors and Ergonomics 3, 4956-4963. URL: http://ac.els-cdn.com/S2351978915006411/1-s2.0S2351978915006411-main.pdf? tid=b63fab56-a688-11e6-abc600000aab0f6c\&acdnat=1478701858 1c95c9cb89678f038afb91fed3007b9c

2. Barrault, S. Marzal, H. Chevalier, F. 2012. Risk Management of Major Industrial Complex Sites: Key Success Factors - OCP Example. International Symposium on Innovation and Technology in the Phosphate Industry. 46, 285-287. URL: http://ac.els-cdn.com/S1877705812045377/1-s2.0-S1877705812045377- 
main.pdf? tid=76d45334-a694-11e6-856900000aacb35e\&acdnat $=1478706906$ c3674df38d45d1f1f2e7ca9e05e80293

3. Statistical year book 2016: http://mospi.nic.in/mospi_new/upload/SYB2016/ch14.html. Assessed Feb 22, 2016.

4. Accidental Deaths and suicides in India Report: http://ncrb.gov.in/StatPublications/ADSI/PrevPublications.html. Assessd Feb 22, 2016.

5. Rezaian, S. Jozi, S. A. 2012. Health- Safety and Environmental Risk Assessment of Refineries Using of Multi Criteria Decision Making Method. International Conference on Chemistry and Chemical Process. 3, 235-238. URL: $\quad$ http://ac.els-cdn.com/S2212670812001467/1-s2.0-S2212670812001467-main.pdf? tid=2202eafa-a69411e6-a6dc-00000aab0f27\&acdnat=1478706763 fa7b09f451396e92b27baf47dd10991f

6. Yi, K. H. Lee, S. S. 2016. A Policy Intervention Study to Identify High-Risk Groups to Prevent Industrial Accidents in Republic of Korea. Safety and Health at Work. 213-217.

7. Babrauskas, V. 2016. Explosions of ammonium nitrate fertilizer in storage or transportation are preventable accidents. Journal of Hazardous Materials. 304, 134-149.

8. Mihailidou, E. K. Antoniadis, K. D. Assael, M. J. 2012. The 319 Major Industrial Accidents since 1917. International Review of Chemical $\quad$ Engineering $4, \quad 6 . \quad$ URL: http://www.hristov.com/jordan/pdfs/The\%20319\%20Major\%20Industrial\%20Accidents\%20Since\%201917IRECHE VOL $4 \mathrm{~N}$ 6.pdf

9. Moreno, V. C. Giacomini, E. Cozzani, V. 2016. Identification of Major Accident Hazards in Industrial Biological Processes. 48. URL: http://www.aidic.it/cet/16/48/114.pdf

10. Olivares, R. D. C, Rivera, S. S. Mc Leod, J. E. N. 2015. Database for accidents and incidents in the fuel ethanol industry. Journal of Loss Prevention in the Process Industries. 38, 276-297.

11. Moura, R. Beer, M. Patelli, E. Lewis, J. Knoll, F. 2016. Learning from major accidents to improve system design. 84, 37-45.

12. Sovacool, B. K. Andersen, R. Sorensena, S. Sorensen, K. Tienda, V. Vainorius, A. Schirach, O. M. Thygesen, F. B. 2016. Balancing safety with sustainability: assessing the risk of accidents for modern low carbon energy systems. Journal of Cleaner Production. 112, 3952-3965.

13. Chinniah, Y. 2015. Analysis and prevention of serious and fatal accidents related to moving parts of machinery. 75, 163-173

14. Caparros, F. S. Cebador, M. S. Rubio-Romero, J. C. 2015. Analysis of investigation reports on occupational accidents. 72, 329-336.

15. Sengupta, A. Bandyopadhyay, D. van Westen, C. J. van der Veen, A. 2016. An evaluation of risk assessment framework for industrial accidents in India. 41, 295-302.

16. Taylan, O. Kabli, M. R. Saeedpoor, M. Vafadarnikjoo, A. 2015. Commentary on 'Construction projects selection and risk assessment by Fuzzy AHP and Fuzzy TOPSIS methodologies'. Applied Soft Computing. 36, 419-421..

17. Veland, H. Aven, T. 2015. Improving the risk assessments of critical operations to better reflect uncertainties and the unforeseen. Safety Science. 79, 206-212. URL: http://ac.els-cdn.com/S092575351500154X/1-s2.0S092575351500154X-main.pdf? tid=7d87cf74-a691-11e6-b16400000aab0f01\&acdnat $=1478705628$ 4c6c19ad0cba3f20302ce25fd34e755c

18. Rouvroye, J. L. Van den Bliek, E. G. 2002. Comparing safety analysis techniques. Reliability Engineering \& System Safety. 75, 289-294.

19. Khan, F. Rathnayaka, S. Ahmed, S. 2015. Methods and models in process safety and risk management: Past, present and future. 98, 116-147.

20. Masto, R. E. George, J. Rout, T. K. Ram, L. C. 2015. Multi element exposure risk from soil and dust in a coal industrial area. Journal of Geochemical Exploration.

21. Burgherr, P. Eckle, P. Hirschberg, S. 2012. Comparative assessment of severe accident risks in the coal, oil and natural gas chains. Reliability Engineering \& System Safety. 105, 97-103.

22. Carbajo, J. B. Perdigón-Melón, J. A. Petre, A. L. Rosal, R. Letón, P. García-Calvo, E. 2015. Personal care product preservatives: Risk assessment and mixture toxicities with an industrial wastewater. Occurrence, fate, removal and assessment of emerging contaminants in water in the water cycle (from wastewater to drinking water). 72, 174-185.

23. Wang, H. Yan, Z. G. Li, H. Yang, N. Leung, K. M. Y. Wang, Y. Yu, Z. Zhang, L. Wang, W. H. Jiao, C. Y. Liu, Z. T. 2012. Progress of environmental management and risk assessment of industrial chemicals in China. Chemicals Management and Environmental Assessment of Chemicals in China. 165, 174-181.

24. Topuz, E, Talinli, I. Aydin, E. 2011. Integration of environmental and human health risk assessment for industries using hazardous materials: A quantitative multi criteria approach for environmental decision makers. Environment International. 37, 393-403.

25. Narayanagounder, S. Gurusami, K. 2009. A New Approach for Prioritization of Failure Modes in Design FMEA using ANOVA. World Academy of Science, Engineering and Technology. International Journal of Social, Behavioral, Educational, Economic, Business and Industrial Engineering. 3, $1 . \quad$ URL; http://waset.org/publications/6947/a-new-approach-for-prioritization-of-failure-modes-in-design-fmea-using-anova

26. Ju, W. H. 2016. Study on Fire Risk and Disaster Reducing Factors of Cotton Logistics Warehouse Based on Event and Fault Tree Analysis. 135, 418-426. URL: http://ac.els-cdn.com/S1877705816001545/1-s2.0- 
S1877705816001545-main.pdf? tid=78bdb3c0-a68f-11e6-ba69-

$\underline{00000 \mathrm{aab} 0 f 26 \& a c d n a t=1478704761 \quad 85 f 64 \mathrm{~b} 729+5 \mathrm{~b} f 28965 \mathrm{a} 69+5990 \mathrm{eb} 16 \mathrm{e} 7}$

27. Wu, D. Chen, Z. 2016. Quantitative risk assessment of fire accidents of large scale Oil tanks triggered by lightning. Engineering Failure Analysis. 63. 172-181.

28. Dunjó, J. Fthenakis, V. Vílchez, J. A. Arnaldos, J. 2010. Hazard and operability (HAZOP) analysis. A literature review. 173, 19-32.

29. Isimite, J. Rubini, P. 2016. A dynamic HAZOP case study using the Texas City refinery explosion. Journal of loss prevention in the process industries. 40, 496-501.

30. Pöykiö, R. Mäkelä, M. Watkins, G. Nurmesniemi, H. Dahl, O. 2016. Heavy metals leaching in bottom ash and fly ash fractions from industrial-scale BFB-boiler for environmental risks assessment. Transactions of Nonferrous Metals Society of China. 26, 256-264.

31. Wachter, J. K. Yorio, P. L. 2014. A system of safety management practices and worker engagement for reducing and preventing accidents: An empirical and theoretical investigation. Accident Analysis \& Prevention. 68, 117130. URL: http://ac.els-cdn.com/S0001457513002972/1-s2.0-S0001457513002972-main.pdf? tid=1fa3d61ca68e-11e6-bde3-00000aacb35f\&acdnat=1478704182 b2e5bd66c6c17f3a93c0218a6ba05683

32. Hauge, K. H. Blanchard, A. Andersen, G. Boland, R. Grøsvik, B. E. Howell, D. Meier, S. Olsen, E. Vikebø, F. 2014. Inadequate risk assessments - A study on worst-case scenarios related to petroleum exploitation in the Lofoten area. Marine Policy. 44, 82-89. URL: http://ac.els-cdn.com/S0308597X13001504/1-s2.0S0308597X13001504-main.pdf? tid=98cdca12-a68d-11e6-9e6700000aab0f02\&acdnat $=1478703956$ 76a5216077b7ec9c9558207e2d31abf0

33. Ilangkumaran, M. Karthikeyan, M. Ramachandran, T. Boopathiraja, M. Kirubakaran, B. 2015. Risk analysis and warning rate of hot environment for foundry industry using hybrid MCDM technique. Safety Science. 72, 133143.

34. Shafiee, M. 2015. A fuzzy analytic network process model to mitigate the risks associated with offshore wind farms. Expert Systems with Applications. 42, 2143-2152.

35. Carlsson, C. Fuller, R. 1996. Fuzzy multiple criteria decision making: Recent developments. Fuzzy sets and Systems. 78, 139-153.

36. Peng, Y. Zhang, Y. Tang, Y. Li, S. 2011. An incident information management framework based on data integration, data mining, and multi criteria decision making. Multi criteria decision making and decision support systems. 51, 316-327.

37. Dağdeviren, M. Yüksel, I. Kurt, M. 2008. A fuzzy analytic network process (ANP) model to identify faulty behavior risk (FBR) in work system. 46, 771-783.

38. Zheng, G. Zhu, N. Tian, Z. Chen, Y. Sun, B. 2012. Application of a trapezoidal fuzzy AHP method for work safety evaluation and early warning rating of hot and humid environments. 50, 228-239.

39. Song, Z. Zhu, H. Jia, G. He, C. 2014. Comprehensive evaluation on self-ignition risks of coal stockpiles using fuzzy AHP approaches. Journal of Loss Prevention in the Process Industries. 32, 78-94.

40. Majumder, D. Debnath, J. Biswas, A. 2013. Risk Analysis in Construction Sites Using Fuzzy Reasoning and Fuzzy Analytic Hierarchy Process. International Conference on Computational Intelligence: Modeling Techniques and Applications. 10, 604-614. URL: http://ac.els-cdn.com/S221201731300563X/1-s2.0-S221201731300563Xmain.pdf? tid=1089ae92-a68c-11e6-905600000aacb35d\&acdnat=1478703298 bdfd75b8c6ab89f1ca647b858f1378de

41. Shiliang, S. Min, J. Yong, L. Runqiu, L. 2012. Risk assessment on falling from height based on AHP-fuzzy. International Symposium on Safety Science and Technology. 45, 112 - 118. URL: http://ac.elscdn.com/S1877705812031426/1-s2.0-S1877705812031426-main.pdf? tid=4fcd8cf4-a68c-11e6-8c8500000aacb35e\&acdnat $=14787034045 f 041$ ec0689d170b64366d284e6ce12e

42. Askari, M. Shokrizadeh, H. R. Ghane, N. 2014. Fuzzy AHP Model in Risk Ranking. European Journal of Business and Management. 6, 14. URL: file:///C:/Users/ADMIN/Downloads/13347-15208-1-PB.pdf

43. Shapira, A. Goldenberg, M. 2005. AHP-Based Equipment selection Model for Construction Projects. Journal of Construction Engineering and Management 131, 1263-1273.

44. Tah, J. H. M. Carr, V. 2000. A proposal for construction project risk assessment using fuzzy logic. Construction Management and Economics. 18, 491-500.

45. Enchill, E. Nyamah, E. Y. 2015. AHP Application in Occupational Safety Analysis In An Industrial Gas Manufacturing Company (Ghana). International journal of management and economics invention. 1, 99-103. URL: http://www.rajournals.in/images/ijmeiarticle/v1-i3/1ijmei.pdf

46. Podgórski, D. 2015. Measuring operational performance of OSH management system - A demonstration of AHPbased selection of leading key performance indicators. 73, 146-166. URL: https://pdfs.semanticscholar.org/55e9/6a6dc56c5206efde3f2591bb9579da714867.pdf 


$$
\begin{array}{r}
\text { ISSN } 2321-807 x \\
\text { Jolume } 13 \text { Number11 } \\
\text { Volumal of Advances in chemistry }
\end{array}
$$

47. Saaty, T. L. 1980. The Analytic Hierarchy Process. McGraw-Hill, New York.

48. Saaty, T. 1996. Decision Making with Dependence and Feedback: The Analytic Network Process. RWS Publications, Pittsburgh, PA.

49. Saaty, T. L. 2001. The Analytic Network Process: Decision Making with Dependence and Feedback. RWS Publications, Pittsburgh, PA 15123, USA.

50. Saaty, T. L. 2005. Theory and Applications of the Analytic Network Process: Decision Making with Benefits, Opportunities, Costs, and Risks. RWS Publications, Pittsburg, PA, USA.

51. Rosaria de, F. S. M. Russo Camanho, R. 2015. Criteria in AHP: A Systematic Review of Literature. International journal of information technology and quantitative management 55, 1123-1132. URL: https://ai2-s2pdfs.s3.amazonaws.com/0682/427c652bd46745c03d7706c91413426230a1.pdf

Appendix 1. Questionnaire pattern for the AHP analysis of three main criteria and seventeen sub criteria GUIDELINES

Go through the following questionnaire and make appropriate marks on the questionnaire. Please use the following marks:

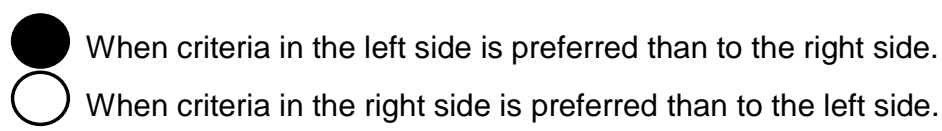

I. Main criteria:

1. How important is the human safety when compared with machine safety?

2. How important is human safety when compared with work environment safety?

3. How important is machine safety when compared with work environment safety?

II. Sub-criteria:

Ila. Human safety:

1. How important is eye protection when compared with manual lifting?

2. How important is eye protection when compared with material handling practices?

3. How important is eye protection when compared with fire fighting drills?

4. How important is eye protection when compared with training?

5. How important is eye protection when compared with safety officer?

6. How important is manual lifting when compared with material handling practices?

7. How important is manual lifting when compared with fire fighting drills?

8. How important is manual lifting when compared with training?

9. How important is manual lifting when compared with safety officer?

10. How important is material handling practices when compared with fire fighting drills?

11. How important is material handling practices when compared with training?

12. How important is material handling practices when compared with safety officer?

13. How important is fire fighting drills when compares with training?

14. How important is training when compared with safety officer?

Ilb. Machine safety:

1. How important is fencing when compared with revolving parts protection?

2. How important is fencing when compared with safe wok speed?

3. How important is fencing when compared with pressure plant protects?

4. How important is fencing when compared with power cut-off devices?

5. How important is revolving parts protection when compared with safe work speed?

6. How important is revolving parts protection when compared with pressure plant protection?

7. How important is revolving parts protection when compared with power cut-off devices?

8. How important is safe work speed when compared with pressure plant protection?

9. How important is safe work speed when compared with power cut-off devices?

10. How important is pressure plant protection when compared with power cut-off devices?

Ilc. Work environment safety:

1. How important is manhole protection when compared with explosion safety?

2. How important is manhole protection when compared with lightening protection?

3 . How important is manhole protection when compared with flammable dust prevention?

4. How important is manhole protection when compared with pits sumps protection?

5. How important is manhole protection when compared with portable light usage?

6. How important is explosion safety when compared with lightening protection?

7. How important is explosion safety when compared with flammable dust prevention?

8. How important is explosion safety when compared with pits, sumps protection?

9. How important is explosion safety when compared with portable light usage?

5981 | P a g e

March 2017

w w w. cirworld.com 
10. How important is lightening protection when compared with flammable dust prevention?

11. How important is lightening protection when compared with pits, sumps protection?

12. How important is lightening protection when compared with portable light usage?

13. How important is flammable dust prevention when compared with pits, sumps protection?

14. How important is flammable dust prevention when compared with portable light usage?

15. How important is pits, sumps protection when compared with portable light usage?

III. Industry wise sub-criteria comparison:

Please read the following questions and make appropriate check marks for each sub-criterion.

1. How important is heavy engineering industry when compared with automobile industry?

2. How important is heavy engineering industry when compared with manufacturing industry?

3. How important is heavy engineering industry hen compared with foundry industry?

4. How important is heavy engineering industry when compared with textile industry?

5. How important is automobile industry when compared with manufacturing industry?

6. How important is automobile industry when compared with foundry industry?

7. How important is automobile industry when compared with textile industry?

8. How important is manufacturing industry when compared with foundry industry?

9. How important is manufacturing industry when compared with textile industry?

10. How important is foundry industry when compared with textile industry

\begin{tabular}{|c|c|c|c|c|c|c|c|}
\hline $\begin{array}{c}Q \\
\text { No }\end{array}$ & Criteria's/Sub-criteria's & $\begin{array}{c}\text { Equally } \\
\text { important } \\
(1,1,1)\end{array}$ & $\begin{array}{c}\text { Slightly } \\
\text { important } \\
\text { than other } \\
(1,3,5)\end{array}$ & $\begin{array}{c}\text { Strong } \\
\text { important } \\
(3,5,7)\end{array}$ & $\begin{array}{c}\text { Very strong } \\
\text { important } \\
(5,7,9)\end{array}$ & $\begin{array}{c}\text { Absolute } \\
\text { important } \\
(9,9,10)\end{array}$ & Criteria's/Sub-criteria's \\
\hline \multicolumn{8}{|c|}{ Main Criteria } \\
\hline 1 & Human safety & & & & & & Machine safety \\
\hline 2 & Human safety & & & & & & Work environment safety \\
\hline 3 & Machine safety & & & & & & Work environment safety \\
\hline \multicolumn{8}{|c|}{ Sub-criteria: Human safety } \\
\hline 4 & Eye Protection & & & & & & Manual lifting \\
\hline 5 & Eye Protection & & & & & & Material handling practices \\
\hline 6 & Eye Protection & & & & & & Fire fighting drills \\
\hline 7 & Eye Protection & & & & & & Training \\
\hline 8 & Eye Protection & & & & & & Safety officer \\
\hline 9 & Manual lifting & & & & & & Material handling practices \\
\hline 10 & Manual lifting & & & & & & Fire fighting drills \\
\hline 11 & Manual lifting & & & & & & Training \\
\hline 12 & Manual Lifting & & & & & & Safety officer \\
\hline 13 & Material handling practices & & & & & & Fire fighting drills \\
\hline 14 & Material handling practices & & & & & & Training \\
\hline 15 & Material handling practices & & & & & & Safety officer \\
\hline
\end{tabular}

5982 | P a g e 
Safety officer

Sub-criteria: Machine safety

19

20

21

22

$$
\begin{aligned}
& \text { Fencing } \\
& \text { Fencing } \\
& \text { Fencing } \\
& \text { Fencing }
\end{aligned}
$$

Revolving parts protection

Revolving parts protection

Revolving parts protection

Safe work speed

Safe work speed

Pressure plant protection

Sub-criteria: Work environment safety

$$
\text { Manhole Protection }
$$

Manhole protection

Manhole protection

Manhole protection

Manhole protection

Explosion safety

$$
\text { Explosion safety }
$$

Explosion safety

$$
\text { Explosion safety }
$$

Lightening protection

$$
\text { Lightening protection }
$$

Lightening protection

Flammable dust prevention

Flammable dust prevention

Pits, sumps protection

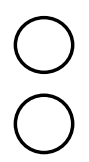

0

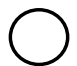

0

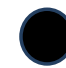

0

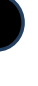

$\bigcirc$
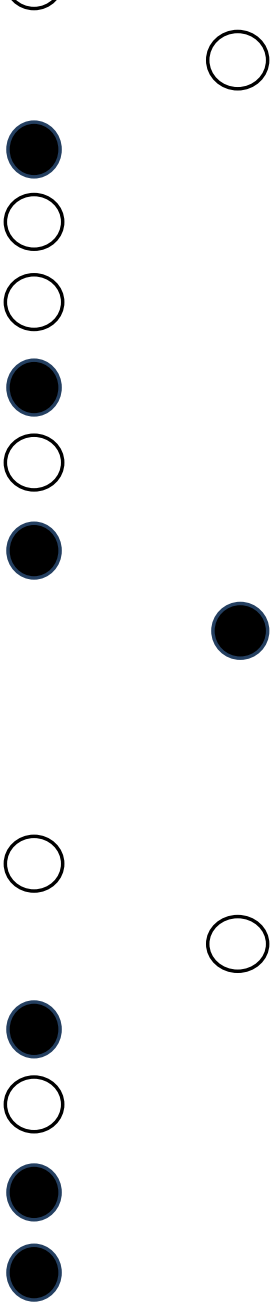

Safe work speed

Pressure plant protection

Power cut-off devices

Safe work speed

Pressure plant protection

Power cut-off devices

Pressure plant protection

Power cut-off devices

Power cut-off devices

Explosion safety

Lightening protection

Flammable dust prevention

Pits. Sumps protection

Portable light usage

Lightening protection

Flammable dust prevention

Pits. Sumps protection

Portable light usage

Flammable dust prevention

Pits. Sumps protection

Portable light usage

Pits. Sumps protection

Portable light usage

Portable light usage 
Industries: Eye Protection

44

45

46

47

48

49

50

51

52

53

54

55

56

57

58

59

60

61

62

63

Industries: Material handling practices

64

65

66

67

68

69

Heavy engineering

Heavy engineering

Heavy engineering

Heavy engineering

Automobile

Automobile

Automobile

Manufacturing

Manufacturing

Foundry

Industries: Manual lifting

$$
\text { Heavy engineering }
$$

Heavy engineering

Heavy engineering

Heavy engineering

Automobile

Automobile

Automobile

Manufacturing

Manufacturing

avy engineering

Heavy engineering

Heavy engineering

Heavy engineering

Automobile

Automobile

Automobile

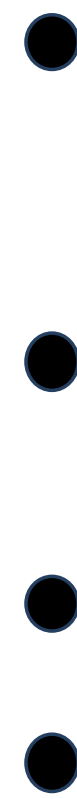

Automobile

Manufacturing

Foundry

Textile Industry

Manufacturing

Foundry

Textile Industry

Foundry

Textile Industry

Textile Industry

Automobile

Manufacturing

Foundry

Textile Industry

Manufacturing

Foundry

Textile Industry

Foundry

Textile Industry

Textile Industry

Automobile

Manufacturing

Foundry

Textile Industry

Manufacturing

Foundry

Textile Industry 
Manufacturing

Industries: Fire fighting drills

Heavy engineering

Heavy engineering

Heavy engineering

Automobile

Automobile

Automobile

Manufacturing

Manufacturing

Foundry

Industries: Training

84

85

86

87

88

89

90

91

92

93
Heavy engineering

Heavy engineering

Heavy engineering

Heavy engineering

Automobile

Automobile

Automobile

Manufacturing

Manufacturing

Foundry

Industries: Safety officer

Heavy engineering

Heavy engineering

Heavy engineering

Heavy engineering
Automobile

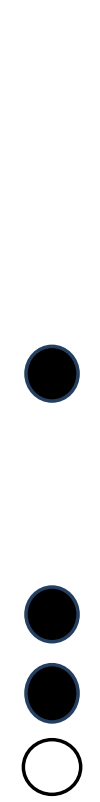

Manufacturing

Foundry

Textile Industry

Manufacturing

Foundry

Textile Industry

Foundry

Textile Industry

Textile Industry

Automobile

Manufacturing

Foundry

Textile Industry

Manufacturing

Foundry

Textile Industry

Foundry

Textile Industry

Textile Industry

Automobile

Manufacturing

Foundry

Textile Industry 
Automobile

Manufacturing

99

Automobile

Foundry

100

Automobile

Textile Industry

Manufacturing

Foundry

102

Manufacturing

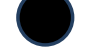

Textile Industry

103

Foundry

Textile Industry

Industries: Fencing

104

Heavy engineering

105

Heavy engineering

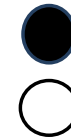

Automobile

Manufacturing

Foundry

Textile Industry

Manufacturing

Foundry

Automobile

Automobile

Manufacturing

112

Manufacturing

113

Foundry

Industries: Revolving parts protection

Heavy engineering

Heavy engineering

Heavy engineering

Heavy engineering

Automobile

Automobile

Automobile

Manufacturing

Manufacturing

Foundry

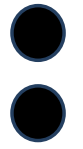

Automobile

Manufacturing

Foundry

Textile Industry

Manufacturing

Foundry

Textile Industry

Foundry

Textile Industry

Textile Industry

Industries: Safe work speed

Heavy engineering

Automobile 
Manufacturing

Automobile

Automobile

Automobile

Manufacturing

Textile Industry

Manufacturing

Foundry

Textile Industry

Foundry

Textile Industry

Textile Industry

Industries: Pressure plant protection

Heavy engineering

Automobile

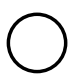

Automobile

Automobile

Manufacturing

Manufacturing

Foundry

Industries: Power cut-off devices

145 Heavy engineering

Manufacturing

Foundry

Textile Industry

Manufacturing

Foundry

Automobile 
Industries: Manhole protection

Automobile

Automobile

Manufacturing

$$
\text { Foundry }
$$

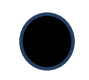

Manufacturing

Foundry

Textile Industry

Foundry

Textile Industry

Textile Industry

Industries: Explosion safety

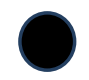

Automobile

Heavy engineering

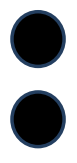

Manufacturing

Heavy engineering

Heavy engineering

Automobile

Automobile

Automobile

Manufacturing

Industries: Lightening protection

Textile Industry

Manufacturing

\section{Foundry}

Textile Industry

\section{Foundry}

Textile Industry

Textile Industry

Heavy engineering

\section{Foundry}

Textile Industry

Manufacturing

Foundry 
Textile Industry

Industries: Flammable dust prevention

Automobile

Heavy engineering

Automobile

Automobile

Manufacturing

Manufacturing

Foundry

Industries: Pits, sumps protection

Manufacturing

$$
\text { Foundry }
$$

Industries: Portable light usage

Textile Industry

Manufacturing

Foundry

Textile Industry

Foundry

Textile Industry

Textile Industry

Automobile

Manufacturing

Foundry

Textile Industry

Manufacturing

Foundry

Textile Industry

Foundry

Textile Industry

Textile Industry

Automobile

Manufacturing

Foundry 


\section{Author' biography with Photo}

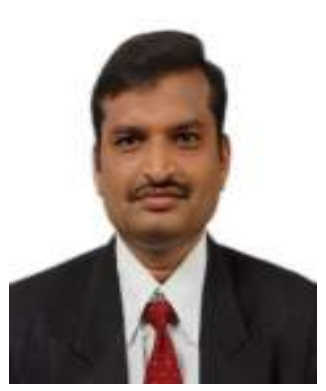

Mr. P. Rajmohan received the B.E. degree in Mechanical Engineering from Bharathiyar University and the M.E. degree in Industrial Safety Engineering from the National Institute of Technology, in 1998 and 2002, respectively. He is currently working as Assisstant Professor, Department of Mechanical Engineering, Knowledge Institute of Technology, Tamilnadu, India.

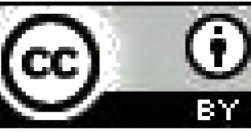

This work is licensed under a Creative Commons Attribution 4.0 International License. 